NBER WORKING PAPER SERIES

\title{
SHORT-RUN MONEY DEMAND
}

\author{
Laurence Ball \\ Working Paper 9235 \\ http://www.nber.org/papers/w9235
}

\section{NATIONAL BUREAU OF ECONOMIC RESEARCH 1050 Massachusetts Avenue \\ Cambridge, MA 02138 \\ October 2002}

I am grateful for research assistance from Gergana Trainor, data from Robert Hetzel, and suggestions from Donald Dutkowsky and seminar participants at the New York Fed. The views expressed herein are those of the authors and not necessarily those of the National Bureau of Economic Research.

(C) 2002 by Laurence Ball. All rights reserved. Short sections of text, not to exceed two paragraphs, may be quoted without explicit permission provided that full credit, including $(C$ notice, is given to the source. 
Short-Run Money Demand

Laurence Ball

NBER Working Paper No. 9235

October 2002

JEL No. E41

\begin{abstract}
The paper estimates a long-run demand function for M1, using U.S. data for 1959-1993. This paper interprets deviations from this long-run relation with Goldfeld's partial adjustment model. A key innovation is the choice of the interest rate in the money demand function. Most previous work uses a short-term market rate, but this paper uses the average return on "near monies" - close substitutes for M1 such as savings accounts and money market mutual funds. This approach yields a predicted path of M1 velocity that closely matches the data. The volatility of velocity after 1980 is explained by volatility in the returns on near monies.
\end{abstract}

\author{
Laurence Ball \\ Department of Economics \\ Johns Hopkins University \\ Baltimore, MD 21218 \\ and NBER \\ lball@jhu.edu
}




\section{INTRODUCTION}

Is there a stable demand function for narrow money? Starting with Poole (1988) and Lucas (1988), there is a growing consensus that long-run money demand is stable. This view is supported by the finding of a cointegrating relation among real M1, interest rates, and output (e.g. Hoffman and Rasche, 1991; Stock and Watson, 1993). At the same time, most researchers view the short-run behavior of money demand -- the fluctuations of real balances around their long-run level -- as unstable and mysterious. Partial-adjustment models of money demand broke down in the 1970s, and attempts to repair them have failed (Goldfeld and Sichel, 1990). M1 velocity has fluctuated a lot since the early 1980s, and observers attribute this fact to unexplained shifts in money demand (e.g. Mankiw, 1997).

This paper questions the conventional wisdom. It argues that there is in fact a stable money demand function that explains short-run velocity movements. I obtain this result partly by combining ideas from previous work: I integrate current models of long-run money demand with a partial adjustment model from the 1970s. There is, however, one crucial innovation in the approach: the choice of the interest rate in the money demand function. Most previous work uses a short-term market rate such as the Treasury Bill rate or the commercial paper rate. I use instead the average return on "near monies" -- close substitutes for M1 such as savings accounts and money market mutual funds. 
Short-run fluctuations in money holdings are closely tied to movements in near-money returns.

Section II of this paper introduces the return on near monies. I define a "near money" as any bank account with zero maturity that is not part of M1. Equivalently, near monies include all the non-M1 components of M2 except for time deposits. The liquidity of these assets makes them the closest substitutes for $M 1$.

To build intuition, section III looks informally at the data on money and interest rates. Perhaps the biggest puzzle about money demand is the apparent shift in its behavior in the early 1980s. M1 velocity followed a smooth upward trend through the $60 \mathrm{~s}$ and 70s, but this trend broke abruptly with the "velocity shock" of 1981-82; since then, velocity has continued to fluctuate. This history can be explained by the behavior of near-money returns, which also grew smoothly until the 80 s and then became volatile. This behavior reflects deregulation and financial innovation, which made near-money returns more responsive to market interest rates.

Section IV estimates long-run money demand functions for the period 1960 through 1993. (I end the sample in 1993 to avoid the complications caused by "sweep" accounts.) Long-run money demand is stable regardless of whether the interest rate is measured by the return on near monies or a money-market rate (the T-bill rate). However, the deviations of money holdings from their long-run level are smaller with the return on near monies. With 
this interest rate, there is less variation that must be explained by a model of short-run dynamics.

Section $\mathrm{V}$ interprets deviations from long-run money demand with Goldfeld's (1973) partial-adjustment model. When the interest rate is the return on near monies, the model yields reasonable parameter estimates, and it is not rejected in favor of a less structured error-correction model. Most important, the deviations of money holdings from the predictions of the model are small. There is little evidence of shifts in the money demand function, even in the short run.

Section VI concludes the paper.

II. THE RETURN ON NEAR MONIES

Most work on M1 demand measures the opportunity cost of money with a short-term market interest rate -- usually the commmercial paper rate or the Treasury Bill rate. As discussed by Hoffman et al. (1995), the choice of an interest rate is not critical for studies of long-run money demand. Most interest rates follow similar trends, and thus have the same long-run relation to real balances. In contrast, different interest rates have different short-run dynamics, so studies of short-run money demand must choose an interest rate carefully.

Which interest rates affect M1 demand? In theory, the effect of an asset's return on the demand for another asset depends on the substitutability of the assets. The demand for M1 should depend most strongly on the returns to its close 
substitutes. In looking for such "near monies," a natural starting point is assets that are included in M2 but not M1: savings accounts, money market mutual funds, and so on. These assets are close substitutes for M1 because they are highly liquid.

One can refine the definition of near monies by looking within the non-M1 part of $M 2$. All assets in this category are bank accounts with zero maturity, with the exception of time deposits. Time deposits are less liquid than zero-maturity accounts, and hence less perfect substitutes for M1. This fact has led some researchers to deemphasize the M2 aggregate in favor of M2 less time deposits - "zero maturity money," or MzM (Motley, 1988; Carlson and Byrne, 1992). In the same spirit, I exclude time deposits from my definition of near monies. Near monies are defined as the non-M1 components of MZM, or equivalently the nonM1 components of M2 except time deposits. There are three near monies: savings accounts, retail money market mutual funds, and money market deposit accounts. ${ }^{1}$

The three near monies have somewhat different interest rates. For parsimony, I do not examine the individual interest rates, but rather take an average. In each period, the average is weighted by the shares of each asset in total near money. These shares change greatly over time. In the 1960s, near monies

1 Carlson and Byrne's definition of MZM includes an additional asset that is not part of M2: institutional money market funds. To be conservative, I exclude these funds from my definition of nearmonies. 
consisted entirely of savings accounts, but by the 80 s more than half were money market mutual funds and money market deposit accounts. Despite these changes, the series that I construct is a consistent measure of the average return on zero-maturity, nontransaction bank accounts.

The cost of holding M1 rather than a near money is the difference between these assets' returns. The returns on M1 are zero before 1973 but slightly positive thereafter, because some demand deposits pay interest. In the analysis below, I assume that money demand depends on the average return on near monies minus the average return on $M 1$. The results are similar when I do not subtract the return on $\mathrm{M} 1$.

The average returns on near monies and M1 are computed from data on the components of M2 and their returns. These data are maintained by the Federal Reserve Bank of Richmond; see Hetzel (1989) for documentation.

\section{VELOCITY AND INTEREST RATES, 1960-1993}

To build intuition, this section examines informally the behavior of $\mathrm{M} 1$ velocity and alternative interest rates. I consider the period from 1960 through 1993. 1960 is the first full year with data on near-money interest rates. The endpoint of 1993 avoids the complications arising from "sweep" programs, which were introduced in 1994. Under sweep programs, banks move customers' funds between different accounts to reduce required reserves. This behavior complicates the measurement of narrow 
money, as the funds are available for transactions but are not always included in M1. As discussed in the conclusion, future work could address this problem and extend this paper's analysis to the present.

Figure 1 presents annual data on M1 velocity, the Treasury Bill rate $\left(R^{\mathrm{TB}}\right)$, and the return on near monies less the return on M1 $\left(R^{\mathrm{NM}}\right)$. The velocity data show why economists believe that money demand is unstable. Velocity followed a smooth upward trend until 1981, but then it began to fluctuate erratically. These fluctuations led the Federal Reserve to deemphasize M1 targets in 1982 and to stop publishing them at all in 1986 . Historical accounts attribute the velocity movements to shifts in money demand that are "mostly unexplained" (Mankiw, 1997). According to Friedman (1988), the relationship between $M 1$ and income "utterly fell apart" in the 1980s.

This experience becomes less puzzling when we examine the behavior of interest rates. Consider first the Treasury bill rate in the middle panel of Figure 1. The T-bill data suggest explanations for two aspects of velocity behavior. The first is the shift of the long-run velocity trend from positive to slightly negative after 1981. This shift can be explained by a coincident shift in the trend of the T-bill rate, which raised the quantity of money demanded. This story is confirmed by econometric work on long-run money demand, which finds a stable relation between the trends in $M 1$, output, and the $T$-bill rate (e.g. Ball, 2001). 
In addition, the T-bill data get us partway to an explanation for short-run velocity fluctuations. Velocity fell in 1982-83 (the "velocity shock" of the Volcker era), rose in 1984, fell sharply in 1985-87 (the "M1 explosion"), and so on. These velocity shifts are matched almost exactly by changes in the $\mathrm{T}$-bill rate: only in 1990 do the two variables move in opposite directions. Thus, for the period after 1980, one can interpret most changes in velocity as movements along a money demand curve caused by interest-rate changes. There is no need to invoke unexplained shifts in the curve.

However, Figure 1 also shows the problem with this story: it does not fit the period before 1981 . The T-bill rate fluctuated a lot in the late $1960 \mathrm{~s}$ and $70 \mathrm{~s}$ as well as the $80 \mathrm{~s}$. If the Tbill rate affects velocity, velocity should have started fluctuating much earlier. Instead, movements in the T-bill rate did not disturb the smooth velocity trend until the early $80 \mathrm{~s}$, when something seems to have changed. The experience before 1981 explains why the 80 s were surprising: economists were not used to seeing velocity respond to interest-rate movements.

In contrast, the return on near monies can explain velocity behavior both before and after 1981. After 1981, $\mathrm{R}^{\mathrm{NM}}$ fluctuates along with the T-bill rate. Before 1981, it follows the upward trend of the T-bill rate, but its path is smoother. This pattern -- a steady rise through 1981 and then fluctuations -- matches the behavior of velocity. Thus the increase in the volatility of velocity can be explained by increased volatility in $\mathrm{R}^{\mathrm{NM}}$. 
The behavior of $\mathrm{R}^{\mathrm{NM}}$ changed in the $1980 \mathrm{~s}$ because of deregulation and financial innovation. Before the $80 \mathrm{~s}$, nearmonies were mainly savings accounts with regulated interest rates. These rates followed the trend in market rates, but did not respond to short-run fluctuations. Deregulation reduced the rigidity in savings rates. In addition, the 1980s produced near monies with rates that closely track market rates, such as money market mutual funds. As a result, $\mathrm{R}^{\mathrm{NM}}$ started to fluctuate along with $\mathrm{R}^{\mathrm{TB}}$.

In some ways, this story is familiar. Many authors suggest that the instability of velocity reflects deregulation and financial innovation (e.g. Goldfeld and Sichel, 1990). However, these developments are usually viewed as causing a breakdown in the money demand function. In contrast, I interpret them as causing changes in the behavior of interest rates, and hence movements along a stable money demand curve.

IV. DEVIATIONS FROM LONG-RUN MONEY DEMAND

Here I compare long-run money-demand equations with alternative interest rates. There is a long-run cointegrating relation between real balances, income, and interest rates regardless of whether the interest rate is the T-bill rate or $\mathrm{R}^{\mathrm{NM}}$. However, the deviations of actual money holdings from the long-run level are smaller for $\mathrm{R}^{\mathrm{NM}}$.

A. Long-Run Equations

Following Stock and Watson (1993) and Ball (2001), I 
estimate money demand functions of the form

$$
\mathrm{m}-\mathrm{p}=\alpha+\theta_{\mathrm{Y}} \mathrm{Y}+\theta_{\mathrm{R}} \mathrm{R}+\epsilon,
$$

where $\mathrm{m}$ is the $\log$ of $\mathrm{M} 1, \mathrm{p}$ is the $\log$ of the GDP deflator, $\mathrm{Y}$ is the $\log$ of real GDP, $R$ is the level of an interest rate, and $\epsilon$ is an error term. $\theta_{\mathrm{y}}$ is the long-run income elasticity of money demand and $\theta_{\mathrm{R}}$ is the interest-rate semi-elasticity.

Most authors measure $\mathrm{R}$ with the Treasury bill rate or the commercial paper rate. For these interest rates, previous work finds that the variables $m-p, y$, and $R$ are cointegrated of order one. Thus equation ( 1 ) can be interpreted as a cointegrating relation, and the error $\epsilon$ is stationary. Using the Treasury bill rate, I confirm the finding of cointegration for the period 1959:2 through 1993:4. The Johansen test with two or four lags rejects non-cointegration at the one percent level.

Because (1) is a cointegrating relation, one can estimate its parameters with Stock and Watson's (1993) Dynamic OLS estimator (DOLS). Table I presents the results: the income elasticity is 0.53 and the interest rate semi-elasticity is -0.040 . These estimates are close to those of Ball (2001) and Dutkowsky and Cynamon $(2001 \mathrm{~b})$.

I now replace the T-bill rate in equation (1) with the return on near-monies. With this interest rate, there is still a cointegrating relation among $\mathrm{m}-\mathrm{p}, \mathrm{y}$, and $\mathrm{R}$ : the Johansen test rejects non-cointegration at the one percent level with two lags and the five percent level with four lags. These results support Hoffman et al.'s suggestion that different interest rates serve 
equally well in long-run money demand functions, because they have similar trends.

With $\mathrm{R}^{\mathrm{NM}}$ in the money-demand equation, the DOLS estimate of $\theta_{\mathrm{y}}$ is 0.47 , close to the estimate with $\mathrm{R}^{\mathrm{TB}}$. However, the interest rate coefficient $\theta_{R}$ is -0.082 , more than twice the previous estimate. This result reflects the fact that long-run movements in $\mathrm{R}^{\mathrm{NM}}$ are smaller than movements in $\mathrm{R}^{\mathrm{TB}}$. For example, $\mathrm{R}^{\mathrm{NM}}$ rises by 4.5 percentage points from 1960 to 1981 , while $\mathrm{R}^{\mathrm{TB}}$ rises by 11.1 points. With $\mathrm{R}^{\mathrm{NM}}$, a given change in real balances is explained by a smaller change in the interest rate, implying a larger coefficient.

\section{B. Deviations from Long-Run Equations}

The results so far do not tell us whether a money demand function can explain quarter-to-quarter or year-to-year movements in real balances. These movements might be predicted by the long-run equation (1), or they might be deviations from this equation. In the latter case, we need an additional model of short-run dynamics to understand the data.

To see how much equation (1) explains, I examine the path of real balances that it implies, given the paths of output and interest rates. This path is given by

$$
(\mathrm{m}-\mathrm{p}) *=\alpha^{\prime}+\theta_{\mathrm{y}}^{\prime} \mathrm{y}+\theta_{\mathrm{R}}^{\prime} \mathrm{R} \text {, }
$$

where ' denotes an estimate. $\theta_{\mathrm{y}}$ ' and $\theta_{\mathrm{R}}$ ' are DoLs estimates, and $\alpha$ ' is the mean of $(m-p)-\theta_{y}{ }^{\prime} y-\theta_{R}{ }^{\prime} R$. The quantity $(m-p)$ * is an estimate of the long-run equilibrium level of real balances. To interpret the results, I also compute "equilibrium velocity," defined as $v^{*}$ 
$\equiv \mathrm{y}-(\mathrm{m}-\mathrm{p}) *$. I compare $\mathrm{v}$ * to the actual path of velocity $\mathrm{v}$.

Figure 2 presents the results. The top panel compares $v$ to $\mathrm{V}^{*}$ when the interest rate is $\mathrm{R}^{\mathrm{TB}}$, and the bottom panel does the same for $\mathrm{R}^{\mathrm{NM}} \cdot \mathrm{V}$ and $\mathrm{V}^{*}$ are usually closer in the second case. The average value of $\left(\mathrm{v}-\mathrm{v}^{*}\right)^{2}$ is $3.6 \times 10^{-3}$ for $\mathrm{R}^{\mathrm{TB}}$ and $1.4 \times 10^{-3}$ for $R^{N M}$. Thus the use of $R^{N M}$ reduces the apparent size of shortrun velocity fluctuations around the equilibrium level.

The choice of interest rate makes the greatest difference for the period before 1981. For this subsample, the average value of $\left(v-v^{*}\right)^{2}$ is more than three times larger with $R^{\mathrm{TB}}$ than with $R^{\mathrm{NM}}$. As shown above in Figure $1, \mathrm{R}^{\mathrm{TB}}$ fluctuated substantially before 1981. The swings in $\mathrm{R}^{\mathrm{TB}}$ imply corresponding swings in equilibrium velocity, but the actual path of velocity was smooth. $R^{\mathrm{NM}}$ grew more smoothly than $\mathrm{R}^{\mathrm{TB}}$, and thus produces a $v^{*}$ path that more closely matches $v$.

The results for $R^{N M}$ suggest again that money demand is not very mysterious. The increased volatility of velocity after 1980 corresponds to increased volatility in $\mathrm{v}^{*}$. Indeed, the "velocity shock" of 1981-82 is overexplained by the long-run money-demand function: given the sharp fall in $R^{\mathrm{NM}}, v^{*}$ falls even more than $v$. overall, the long-run equation explains much of the velocity behavior that has puzzled researchers.

V. A PARTIAL ADJUSTMENT MODEL

The previous section shows that a long-run money demand equation explains much of the behavior of velocity. Here I go a 
step farther to explore deviations from the long-run relation. It turns out that Goldfeld's (1973) partial adjustment model explains most of these deviations. Once again, the choice of an interest rate is crucial for the results.

\section{A. The Behavior of Nominal Money}

To motivate the partial-adjustment model, I first examine the data from a new angle. Figure 3 shows the path of nominal money, m. It also shows the path of money implied by the longrun money demand function with $\mathrm{R}=\mathrm{R}^{\mathrm{NM}}$. This path is $\mathrm{m} *=$ ( $\mathrm{m}-$ $p) *+p$, where $(m-p) *$ is given by equation (2). Note that the deviations of actual from equilibrium money, $m-m^{*}$, are the same as the velocity deviations $v-v^{*}$ examined above. However, comparing $m$ and $m *$ provides intuition about the behavior of short-run money demand.

Specifically, in Figure 3, actual money $\mathrm{m}$ appears to be a smoothed version of equilibrium money $m *$. The two variables follow the same upward trend, but $m$ fluctuates less: the variance of the change in $\mathrm{m}$ is $1.1 \times 10^{-4}$, compared to $4.0 \times 10^{-4}$ for the change in $m *$. Thus the differences between actual and equilibrium money do not appear to reflect short-run shifts in money demand, which would cause $m$ to fluctuate around $m$ * Instead, there seems to be some stickiness in $\mathrm{m}$. Partialadjustment models are designed to explain such behavior.

B. The Model

I assume that money holdings differ from $\mathrm{m}^{*}$, the long-run equilibrium level, for two reasons. First, there are transitory 
shocks to desired money holdings arising from shifts in tastes or technology. Desired money holdings are $\mathrm{m}^{*}+\eta$, where $\eta$ follows a stationary process with zero mean.

Second, actual money holdings do not adjust fully to the desired level. Current $m$ depends partly on $m^{*}+\eta$ and partly on lagged $\mathrm{m}$ :

$$
\mathrm{m}=\mathrm{k}+\mu\left(\mathrm{m}^{*}+\eta\right)+(1-\mu) \mathrm{m}_{-1}, \mathrm{k}>0, \quad 0<\mu<1 .
$$

Equation (3) is optimal if agents suffer quadratic losses from changes in $\mathrm{m}$ and from deviations of $\mathrm{m}$ from $\mathrm{m} *+\eta$. The parameter $\mu$ is the speed of adjustment of money holdings. The constant $k$ arises because $m^{*}$ has a positive trend (see Nickell, 1985).

To estimate this model, I assume that the shock $\eta$ follows an AR-2 process: $\eta=\rho_{1} \eta_{-1}+\rho_{2} \eta_{-2}+v$. Quasi-differencing equation (3) leads to

$$
\begin{aligned}
\mathrm{m}= & \mathrm{k}\left(1-\rho_{1}-\rho_{2}\right)+\left(1-\mu+\rho_{1}\right) \mathrm{m}_{-1}+\left(\mu \rho_{1}-\rho_{1}+\rho_{2}\right) \mathrm{m}_{-2} \\
& -(1-\mu) \rho_{2} \mathrm{~m}_{-3}+\mu\left(\mathrm{m}^{*}-\rho_{1} \mathrm{~m}_{-1}-\rho_{2} \mathrm{~m}_{-2}\right)+\mu \nu .
\end{aligned}
$$

There are four parameters of short-run money demand: $\mu, \mathrm{k}, \rho_{1}$, and $p_{2}$.

Following Duca (2000), I estimate equation (4) with both one-step and two-step methods. In the two-step case, I use the series for $m^{*}$ constructed from the DOLS regression and estimate the parameters of (4) by non-linear least squares. ${ }^{2}$ In the onestep case, I use the long-run money demand function to write $\mathrm{m}$ *

2 DOLS estimates of long-run parameters are super-consistent. Thus these parameters can be treated as known in the second-step regression (there is no generated-regressor problem). 
in terms of $\mathrm{p}, \mathrm{y}$, and $\mathrm{R}$. Then I jointly estimate the parameters of (4) and the parameters of long-run money demand (except the constants $\mathrm{k}$ and $\alpha$, which are not separately identified).

Table II presents the results. In the two-step case, the estimate of the adjustment parameter $\mu$ is 0.20 . Thus money holdings adjust $20 \%$ toward the optimal level in one quarter and $59 \%$ in a year. This adjustment speed is close to estimates from the heyday of partial adjustment models (e.g. Goldfeld, 1973). The transitory money-demand shocks have substantial serial correlation $\left(\rho_{1}=0.54\right.$ and $\left.\rho_{2}=0.21\right)$.

The one-step procedure produces similar estimates of the short-run parameters. In addition, the long-run income and interest-rate coefficients are close to the DoLs estimates in Table I.

Once again, the use of $\mathrm{R}^{\mathrm{NM}}$ is important for the results. When the model is estimated with $\mathrm{R}^{\mathrm{TB}}$ as the interest rate, the adjustment speed is only 0.08 . This result reflects the fact that $\mathrm{R}^{\mathrm{TB}}$ fluctuates before 1980 but velocity is steady, which suggests very slow adjustment.

\section{Another Look at Velocity Fluctuations}

To evaluate the model's fit, note first that the variance of $\mu \eta$, the error in the partial adjustment equation (3), is $1.7 \times 10^{-4}$ (for the two-step estimates). This is only $12 \%$ of the variance of $m-m^{*}$, the deviation of money from its long-run equilibrium. Thus slow adjustment rather than unexplained shocks to money demand explain most of $\mathrm{m}-\mathrm{m}^{*}$. 
Figure 4 compares the path of velocity to the path predicted by the model. The predicted path is derived from the partialadjustment equation (3) with the $\eta$ 's set to zero and the parameters given by two-step estimates. For the first observation (1959:2), I use the actual value of lagged $\mathrm{m}$ in (3); for the other observations, I use the predicted $m$ from the previous period. Given the initial $m_{-1}$ and the series for $m *$, the predicted path shows how velocity would have evolved if there were no shocks to desired money holdings and $\mathrm{m}$ adjusted to $\mathrm{m}$ * at the estimated rate. The Figure shows that predicted and actual velocity are usually close to each other.

Figure 4 helps us understand some famous historical episodes, notably the fall in velocity in 1981-82. Recall from Figure 2 that the long-run money demand equation predicts a larger velocity fall than the one that actually occurred. In contrast, the predicted velocity path in Figure 4 matches the actual path almost perfectly over 1981-82. Slow adjustment explains why actual velocity fell less than equilibrium velocity when interest rates fell.

The partial adjustment model also helps explain other episodes. The sharp fall in velocity over 1985-87 - the "M1 explosion" - is mostly predicted by the model. The model does not fully resolve the "missing money" puzzle of the late 1970s: actual velocity drifts above predicted velocity during that period. However, one can interpret this episode as a moderatesized, transitory shock to money demand, not a breakdown of the 
money-demand relation.

\section{Partial Adjustment vs. Error Correction}

Goldfeld's partial adjustment model broke down in the 1970s, and attempts to repair it have failed. As a result, the partial adjustment model has been "largely abandoned" (Hoffman et al., 1995). In recent years, students of short-run money demand have estimated "error-correction" models that impose fewer theoretical restrictions (e.g. Baba et al [1992], Duca [2000]). These models assume that money eventually moves toward its equilibrium level, but they also allow arbitrary effects of many variables on money growth.

This paper aims to revive the partial adjustment model. Thus it is natural to ask whether the model's assumptions fit the data. The partial adjustment model is a special case of an error-correction model: it includes the same variables, but it imposes restrictions across the coefficients. Here I test these restrictions.

To see the relation between partial-adjustment and errorcorrection models, rearrange equation (4) to obtain

$$
\begin{aligned}
\Delta \mathrm{m} & =\mathrm{k}\left(1-\rho_{1}-\rho_{2}\right)+\mu\left(1-\rho_{1}-\rho_{2}\right)\left(\mathrm{m}^{*}{ }_{-1}-\mathrm{m}_{-1}\right) \\
& +\left(\rho_{1}-\mu \rho_{1}-\mu \rho_{2}\right) \Delta \mathrm{m}_{-1}+(1-\mu) \rho_{2} \Delta \mathrm{m}_{-2}+\mu \Delta \mathrm{m} * \\
& +\mu \rho_{2} \Delta \mathrm{m}{ }_{-1}+\mu \nu .
\end{aligned}
$$

Using the definition of $m *$, this becomes

$$
\begin{array}{r}
\Delta \mathrm{m} \quad=\mathrm{k}\left(1-\rho_{1}-\rho_{2}\right)+\mu\left(1-\rho_{1}-\rho_{2}\right)\left(\mathrm{m}^{*}{ }_{-1}-\mathrm{m}_{-1}\right) \\
+\left(\rho_{1}-\mu \rho_{1}-\mu \rho_{2}\right) \Delta \mathrm{m}_{-1}+(1-\mu) \rho_{2} \Delta \mathrm{m}_{-2}+\mu \Delta \mathrm{p}
\end{array}
$$




$$
\begin{aligned}
& +\mu \rho_{2} \Delta \mathrm{p}_{-1}+\mu \theta_{\mathrm{y}}{ }^{\prime} \Delta \mathrm{y}+\mu \rho_{2} \theta_{\mathrm{y}}{ }^{\prime} \Delta \mathrm{y}_{-1}+\mu \theta_{\mathrm{R}}{ }^{\prime} \Delta \mathrm{R} \\
& +\mu \rho_{2} \theta_{\mathrm{R}}{ }^{\prime} \Delta \mathrm{R}_{-1}+\mathrm{u} \nu
\end{aligned}
$$

Equation (6) is an error-correction model: the change in $\mathrm{m}$ depends on an error-correction term $\left(m^{*}{ }_{-1}-m_{-1}\right)$, lags of the change in $\mathrm{m}$, and current and lagged changes in $\mathrm{p}, \mathrm{y}$, and $\mathrm{R}$. However, once $\theta_{\mathrm{Y}}^{\prime}$ and $\theta_{\mathrm{R}}^{\prime}$ are set at DoLs estimates, the ten coefficients in (6) are determined by only four parameters $\left(k, \mu, \rho_{1}\right.$, and $\left.\rho_{2}\right)$. Thus the partial adjustment model places six restrictions on the error-correction model.

A test of the partial adjustment model based on sums of squared residuals yields an F statistic of 0.7 , with a p-value above 0.5 . Thus the partial adjustment model fits the data. We need not accept the lack of parsimony in error-correction models.

Once again, the choice of an interest rate is crucial to the results. I have also tested the partial adjustment model when the interest rate is the Treasury bill rate rather than $\mathrm{R}^{\mathrm{NM}}$. In this case, the F statistic is $7.6(\mathrm{p}<0.01)$, so the model is rejected.

\section{CONCLUSION}

This paper estimates a long-run money demand function and interprets deviations from this relation with a partial adjustment model. The interest rate in the money demand function is the average return on near monies, such as savings accounts and money market mutual funds. The model explains most of the behavior of M1 velocity from 1960 through 1993. In particular, 
the volatility of velocity after 1980 is explained by volatility in the return on near monies.

The results of this paper have parallels in recent work on M2. Duca (2000) and Carlson et al. (2000) explain the "Missing M2" of the 1990s with decreased costs of holding bond mutual funds, which are substitutes for M2. These papers and mine make the same broad point: apparent instabilities in money demand disappear if one correctly measures the opportunity cost of money •

Future research should extend the analysis from 1993 to the present, which requires accounting for sweep programs. A measure of narrow money should include the balances in sweeps, which are just as liquid as demand deposits. The Federal Reserve does not report sweep balances, but Dutkowsky and Cynamon (2001a, 2001b) estimate them from flows into sweeps. Dutkowsky and Cynamon find that long-run money demand is stable through 2000 when sweeps are included in money. Future work can use the Dutkowsky-Cynamon method to study short-run money demand.

Future research should also address the role of money in monetary policy. Today most economists believe that central banks should set interest rates with little regard to the paths of monetary aggregates. This consensus, however, is based on the view that money demand is unstable. My finding that M1 demand is well-behaved suggests that we should reopen the policy question. 


\section{References}

Baba, Yoshihisa, David F. Hendry and Ross M. Starr, "The Demand for M1 in the U.S.A., 1960-1988," Review of Economic Studies $59: 1(1992), 25-61$.

Ball, Laurence, "Another Look at Long-Run Money Demand," Journal of Monetary Economics 47:1 (2001), 31-44.

Carlson, John B. and Susan M. Byrne, "Recent Behavior of Velocity: Alternative Measures of Money," Federal Reserve Bank of Cleveland Economic Review 28:1 (1992), 2-10.

Duca, John V., "Financial Technology Shocks and the Case of the Missing M2," Journal of Money, Credit, and Banking $32: 4$ $(2000)$.

Dutkowsky, Donald H., and Barry Z. Cynamon, "Sweep Programs: The Fall of $M 1$ and the Rebirth of the Medium of Exchange," Syracuse University (2001a). Journal of Money, Credit, and Banking, forthcoming.

Dutkowsky, Donald H., and Barry Z. Cynamon, "Yet Another Look at Long-Run Money Demand," Syracuse University (2001b).

Friedman, Benjamin M., "Lessons on Monetary Policy from the 1980s," Journal of Economic Perspectives 2 (Summer 1988), $51-72$.

Goldfeld, Stephen M., "The Demand for Money Revisited," Brookings Papers on Economic Activity 3 (1973), 577-638.

Goldfeld, Stephen M., and Daniel E. Sichel, "The Demand for Money," in B. Friedman and F. Hahn (eds.), Handbook of Monetary Economics, Elsevier, 1990, 300-356.

Hetzel, Robert L., "M2 and Monetary Policy," Federal Reserve Bank of Richmond Economic Review 75 (September/October 1989), 1429 .

Hoffman, Dennis L., Robert H. Rasche, and Margie A. Tieslau, "The Stability of Long-Run Money Demand in Five Industrial Countries," Journal of Monetary Economics 35:2 (1995), 317339 .

Hoffman, Dennis L., and Robert H. Rasche, "Long-Run Income and Interest Elasticities of Money Demand in the United States," Review of Economics and Statistics 73:4 (1991), 665-674. 
Lucas, Robert E. Jr., "Money Demand in the United States: A Quantitative Review," Carnegie-Rochester Conference Series on Public Policy 29 (Autumn 1988), 137-168.

Mankiw, N. Gregory, Macroeconomics, $3^{\text {rd }}$ ed., Worth Publishers, 1997 .

Motley, Brian, "Should M2 Be Redefined?," Federal Reserve Bank of San Francisco Economic Review (Winter 1988), 33-51.

Nickell, Stephen, "Error Correction, Partial Adjustment, and All That: An Expository Note," oxford Bulletin of Economics and Statistics 47:2 (1985), 119-129.

Poole, William, "Monetary Policy Lessons of Recent Inflation and Disinflation," Journal of Economic Perspectives 2 (Summer 1988), 73-100.

Stock, James $\mathrm{H}$, and Mark W. Watson, "A Simple Estimator of Cointegrating Vectors in Higher order Integrated Systems," Econometrica 61:4 (1993), 783-820. 
Figure 1

Velocity and Alternative Interest Rates
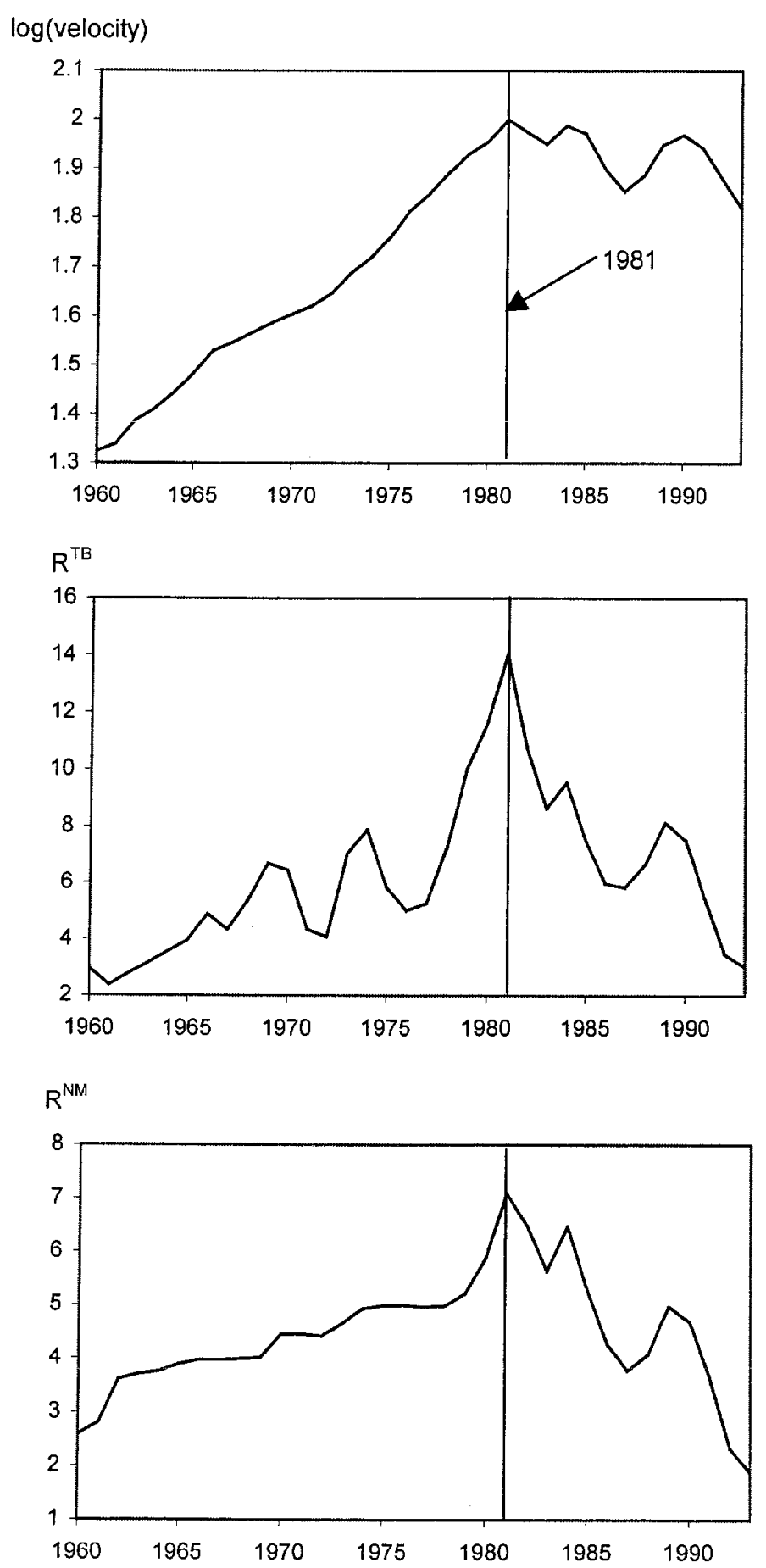
Figure 2

Velocity Fluctuations and Long-Run Money Demand
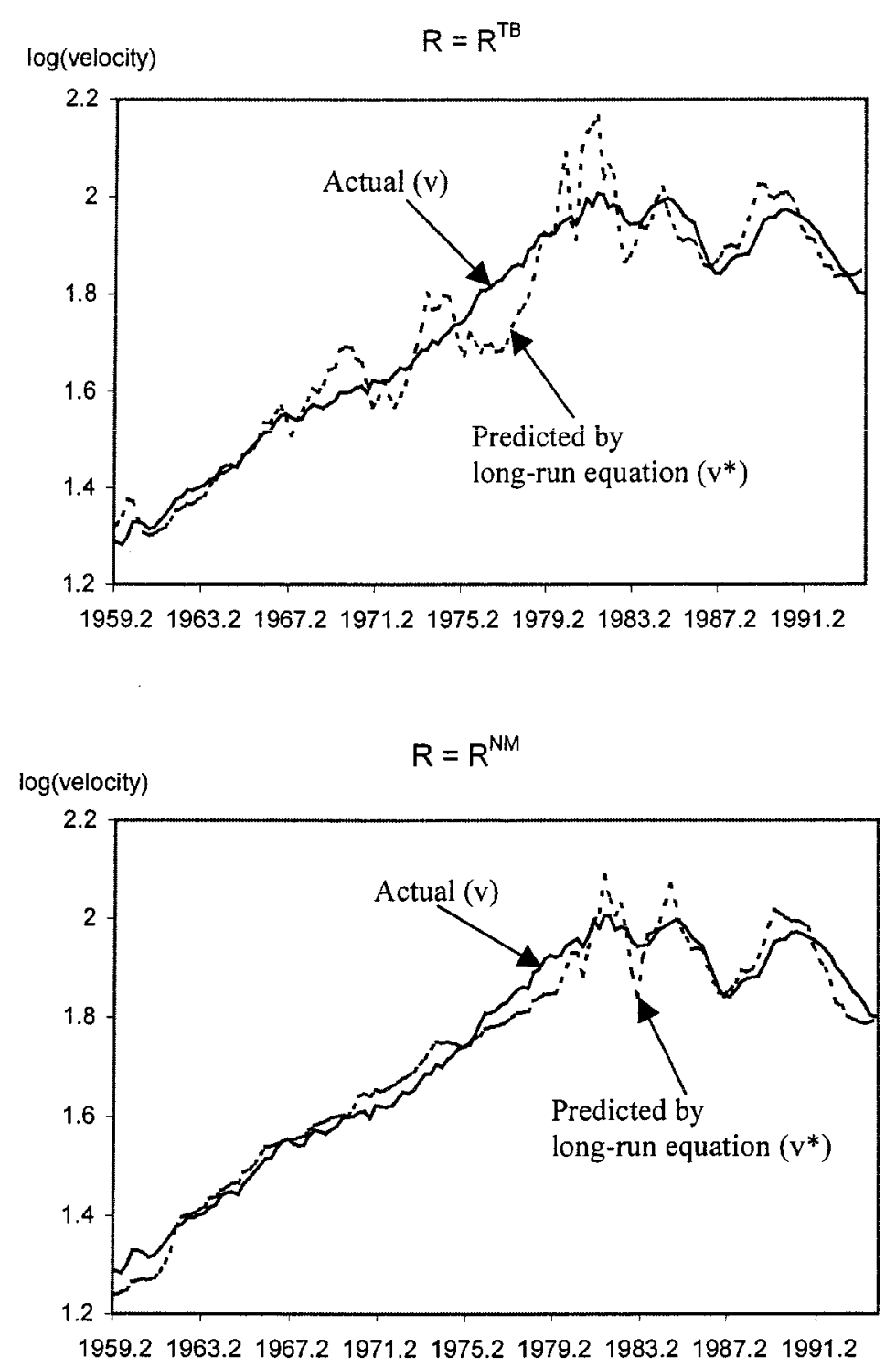
Figure 3

Nominal Money and Long-Run Demand

$\left(\mathrm{R}=\mathrm{R}^{\mathrm{NM}}\right)$

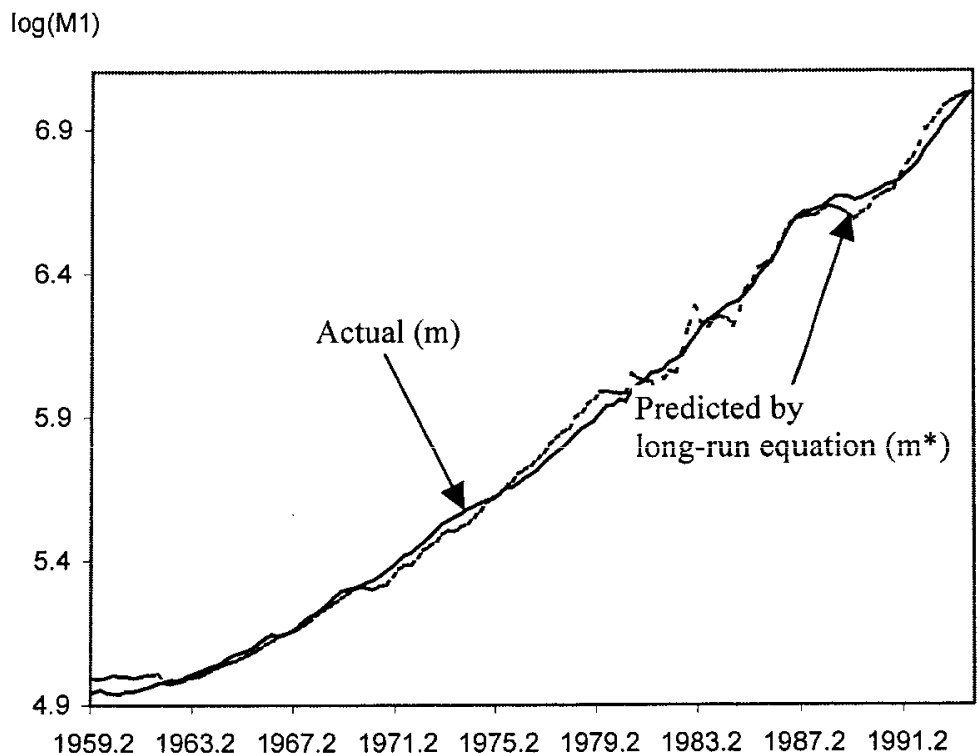

Figure 4

Velocity and the Partial Adjustment Model $\left(R=R^{N M}\right)$

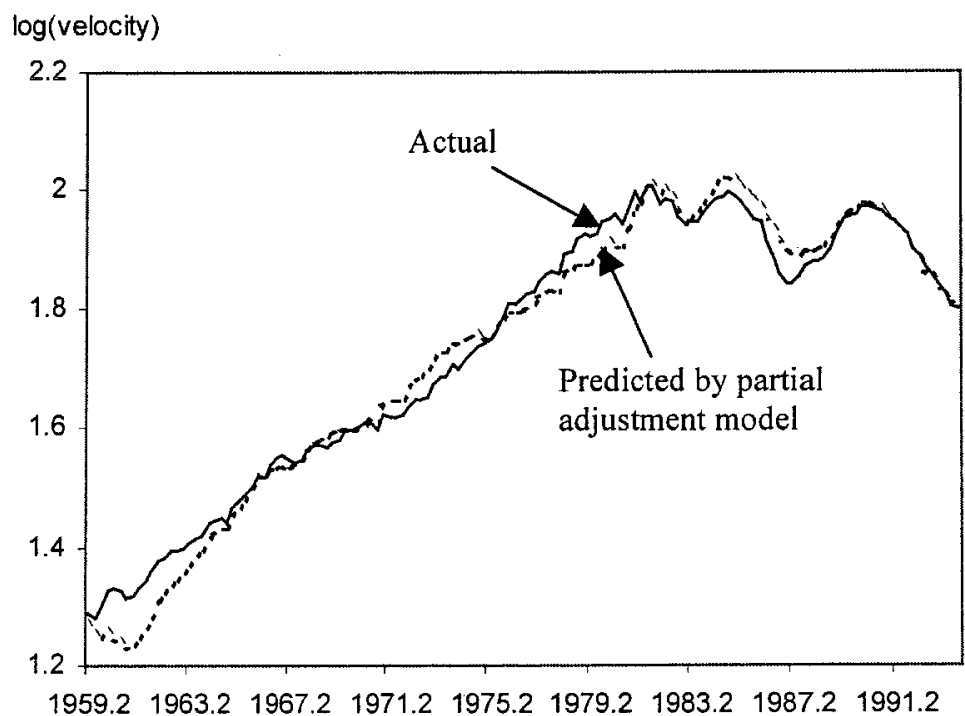


Table 1

Estimates of Long-Run Money Demand Parameters ${ }^{a}$ 1960:3 - 1993:4

\begin{tabular}{|c|c|c|}
\hline & $\underline{R=R^{T B}}$ & $\underline{R}=R^{\mathrm{NM}}$ \\
\hline & & \\
\hline$\theta_{Y}$ & 0.532 & 0.467 \\
\hline & $(0.031)$ & $(0.024)$ \\
\hline$\theta_{R}$ & -0.040 & -0.082 \\
\hline & $(0.003)$ & $(0.006)$ \\
\hline
\end{tabular}

Table 2

Estimates of the Short-Run Model, 1959:4-1993:4 $\left(R=R^{N M}\right)$

\begin{tabular}{|c|c|c|}
\hline & Two-Step & One-Step \\
\hline \multirow[t]{2}{*}{$k$} & 0.012 & (not identified) \\
\hline & $(0.002)$ & \\
\hline \multirow[t]{2}{*}{$\mu$} & 0.204 & 0.204 \\
\hline & $(0.039)$ & $(0.042)$ \\
\hline \multirow{2}{*}{$\rho_{1}$} & 0.538 & 0.509 \\
\hline & $(0.127)$ & $(0.128)$ \\
\hline \multirow[t]{2}{*}{$\rho_{2}$} & 0.215 & 0.191 \\
\hline & $(0.102)$ & $(0.101)$ \\
\hline \multirow[t]{2}{*}{$\theta_{y}$} & $0.467^{6}$ & 0.514 \\
\hline & $(0.024)$ & $(0.029)$ \\
\hline \multirow[t]{2}{*}{$\theta_{R}$} & $-0.082^{6}$ & -0.077 \\
\hline & $(0.006)$ & $(0.006)$ \\
\hline
\end{tabular}

\footnotetext{
${ }^{a}$ Estimation is by Dynamic OLS with four leads and lags. Standard errors in parentheses are calculated using Stock and Watson's (1993) DOLS2 procedure.

${ }^{b}$ DOLS estimates from Table 1.
} 